\title{
ANALYSIS R C OF SILO STRUCTURE
}

\author{
Mr Raju Lamani \\ Dept of civil engg \\ KLS GIT Belagavi, Karnataka
}

\author{
Prof. Rajani Togarsi \\ Dept of civil engg \\ KLS GIT Belagavi, Karnataka
}

\author{
Prof. Pavan Gudi \\ Dept of civil engg \\ KLS GIT Belagavi, Karnataka
}

\begin{abstract}
The development industries mainly need storage bins or larder for storage raw materials. They need extra space for storing raw materials and industrial products. Based on what raw material they are using on that we have to decide which storage structure we should construct. Normally larder will consume more space. We need to lift the material in larder structure and re transport the stored material. Based on all these parameters structural engineering many decades back innovated new elevated structure is silos. Silo structure is used for storing raw material industries. These silo structure consume very less space compare to larder. we need to lift the material one side and that one getting empty by consumption. While consuming the raw material that will flow under gravity force. These silos are working like over head tanks.
\end{abstract}

In this project we analyzed reinforced concrete silo in SAP 2000 software. The analysis results are mode shapes. Horizontal displacement and time period of structure. even we compared the two different type of horizontal displacement. One is horizontal displacement under Live load with wind load. Another one is empty silo with load. The horizontal displacement of reinforced concrete silo is more in empty weight with wind load compared to full fill silo with wind load. Normally we are constructing structure in load combinations and deformation will more in load combinations. But in this silo structure we need analyze the structure in empty condition. That way we should take care design expectation in empty condition.

Keywords- T=Time period in second $F=$ frequency $(\mathrm{r} / \mathrm{sec})$

\section{INTRODUCTION}

The prime objective of constructing silos is to provide sufficient storage capacity of materials in industries. The silos consuming less space and elevated structure. the structures getting more height we need to analyze the structure in lateral) loading conditions. Even in the silos the initially load acting on the side walls of the structure and finally reaches to ground. The silos are cylindrical surface structures then the hoop stresses are developing on the side walls. Normally in the industries they are using steel structures because the structural steel having good behavior under harmonic loading conditions. but installation and fabrication steel silos need expert designer and skilled labors. Transporting cost of structural will be more. The required materials of reinforced concrete silos are available in our local market. The different objectives are considered to analyze and design of reinforced concrete silos. The sap 2000 software is the one of good software for analyzing the RC silos and very popular in now days. We referred some journals they clearly specified that the deformation is more in empty weight structures. that's way In this project we compared two types of reinforced silos. First one is empty weight of silos with lateral wind loading and another one is seismic behavior RC silos with both lateral and vertical loading condition. for both the conditions we used sap 2000 software only. Now we have to discuss about different

\section{LITERATURE SURVEY}

Mr. Sachin Patil, Sonali(2017) this journal clearly specifying about SAP2000 is very economical in columns compare to etabs .when comparing to beam analysis the beam are economical compare to SAP 2000.in this journal the three story symmetrical structure consider for the analyzing they adopted same $\mathrm{p}$ section properties in the both software's. they analyzed the structures even in seismic behavior. The software shown the column result variation $30 \%$ less in sap software compare to etabs .even the beam results also $10 \%$ less compare to etabs software in the $\mathrm{g}$ shear force and bending moments. if the shear force and bending moment values are less, then the consumption reinforcement also less. by referring the sap software we can make the structure economical compare to etabs software. the consumption of material also less. By consuming the less material in constructing structures, we can minimize the natural disorders. Example of natural disorders is flooding, earth quake and deforestation. we have to say very thankful to like this journal writers. Varun. G, Kavan M.R (2017) in this journal they concluded that how the behavior of reinforced silos under seismic loading. They analyzed the different silos with various $\mathrm{H} / \mathrm{D}$ ratios. We need to analyze the structure under seismic loading, because the structures are weak in lateral loading. even many structures are getting collapse under lateral loading. the journal writer took 3 different silo models with different height. The sections assigned for each silo is same. Finally they concluded that the incremental height of silo increases the displacement at top of silos. Even the case study of silo specifying the heavy mass attracts more seismic energy. the $10 \mathrm{~m}$ height silo reaches $373 \mathrm{~mm}$ displacement. the displacement of silos are under the standard code limits. Rajani S Togarsi (2015) the prime object of this journal paper 


\section{International Journal of Engineering Applied Sciences and Technology, 2020 \\ Vol. 5, Issue 2, ISSN No. 2455-2143, Pages 328-332 \\ Published Online June 2020 in IJEAST (http://www.ijeast.com)}

is analyzing the silos under different loading conditions. They modeled the silos using sap software with different supporting structural members. The first silo supported by columns and another silos supported by both column and shear walls. Initially they analyzed the silo under empty loading. After that partially filling and finally full fill condition. This same procedure both the silos. After analyzing the silos in sap software they found the different lateral displacement with respect to height and loading condition. Harshawardhan G. Patil, P.S. Patil (2019) this journal contain the behavior silos under lateral loading. One silos analyzed with empty silo with wind load and another silos full filled with material with wind load. In this case the silos is completely modeled by structural steel. The self weight of silos is very less because of thickness of cylindrical plate is thin. This steel plate is joined by electrical weld. The section properties assigned for the both structural's will be same.

Finally they conclude that the lateral displacement of empty silo is more. Usually we are designing the structures in different load combinations. But here we have to design the silo structure under empty condition, because the displacement of empty silo is more.

\section{OBJECTIVE AND METHODOLOGY}

\section{A) Objectives}

- To study and to compare the seismic parameters such as mode shape, time period and displacement etc.

- The prime objective of study is to find out the maximum horizontal displacement of the structure in both empty and full fill condition under wind load.

- Comparison displacement under empty and full fill condition.

- Maximum displacement will help out to design the structure.

\section{B) Methodology}

1) The reinforced concrete silos structure are modeled using SAP2000 software. The Analyze silos with the different types of structural components and their configuration

2) A linear response spectrum analysis is to be carried out as per Indian standard code (IS 1893:2016 part1)

3) Comparison of the seismic parameters such as base shear, displacement etc.

4) for steel frame with different bracing configuration.

5) Analyzing the reinforced concrete silos under Jonson and airy's theory

6) Comparison the behavior of silos with fully filled and empty condition

\section{C) Modeling and Details of Structure}

SAP2000 means Structural Analysis Program, to make model on SAP2000 anything must be fixed from inputs meaning that material properties, boundary condition, etc.

1) Material Properties: The material of circular silo is reinforced concrete on SAP2000. The silo divided in to three sections which are roof section, main silo section and hopper section

TABLE 1: Material Properties

\begin{tabular}{|c|c|}
\hline \multicolumn{2}{|c|}{ Concrete Properties } \\
\hline Grade of concrete & M25 \\
\hline Modulus of elasticity & $25000 \mathrm{MPa}$ \\
\hline Density of concrete & $25 \mathrm{kN} / \mathrm{m} 3$ \\
\hline Poisson's ratio & 0.2 \\
\hline \multicolumn{2}{|c|}{ Reinforcement Properties } \\
\hline Grade of steel & Fe 500 \\
\hline Mass per unit volume & $7850 \mathrm{~kg} / \mathrm{m} 3$ \\
\hline Modulus of elasticity & $210000 \mathrm{Mpa}$ \\
\hline Poisson's ratio & 0.3 \\
\hline
\end{tabular}

TABLE 2 details of silos

\begin{tabular}{|c|c|}
\hline Total Height of Silo & $9 \mathrm{~m}$ \\
\hline Diameter of silos & $2 \mathrm{~m}$ \\
\hline Height of Bottom & $1 \mathrm{~m}$ \\
\hline Thickness Side Wall & $0.2 \mathrm{~m}$ \\
\hline Thickness of Hopper Bottom & $0.25 \mathrm{~m}$ \\
\hline Hopper of opening & $0.4 \mathrm{~m}$ dia \\
\hline Size of Column & $0.3 \times 0.45 \mathrm{~m}$ \\
\hline No's of Column & 4 No’s \\
\hline $\begin{array}{c}\text { Size of Curved Beam At } \\
\text { Bottom }\end{array}$ & $0.3 \times 0.45 \mathrm{~m}$ \\
\hline $\begin{array}{c}\text { Size of Curved Beam At Top } \\
\text { Of Silo }\end{array}$ & $0.3 \times 0.3 \mathrm{~m}$ \\
\hline $\begin{array}{c}\text { No's of Radians In Circular } \\
\text { Silo }\end{array}$ & 16 Divisions \\
\hline $\begin{array}{c}\text { Density of stored material } \\
\text { (wheat) }\end{array}$ & $8 \mathrm{kN} / \mathrm{m} 3$ \\
\hline $\begin{array}{c}\text { Ratio of horizontal to vertical } \\
\text { pressure }\end{array}$ & 0.44 \\
\hline Angle of repose & 25 Degree \\
\hline Theory for pressure calculation & Janssen's \\
\hline
\end{tabular}


International Journal of Engineering Applied Sciences and Technology, 2020

Vol. 5, Issue 2, ISSN No. 2455-2143, Pages 328-332

Published Online June 2020 in IJEAST (http://www.ijeast.com)

TABLE 3Seismic Parameters as per IS 1893-2016

\begin{tabular}{|c|c|}
\hline Zone (Z) & $\mathrm{V}(0.36)$ \\
\hline Soil type & II (Medium) \\
\hline Importance factor (I) & 1 \\
\hline $\begin{array}{c}\text { Response reduction } \\
\text { factor (R) }\end{array}$ & 4 \\
\hline Damping & $2 \%$ \\
\hline
\end{tabular}

TABLE 4 Horizontal pressure distribution of silo

\begin{tabular}{|c|c|}
\hline $\begin{array}{c}\text { Height of silo from top } \\
(\mathrm{m})\end{array}$ & $\begin{array}{c}\text { Pressure on silo wall } \\
(\mathrm{kN} / \mathrm{m} 2)\end{array}$ \\
\hline 1 & 10.54 \\
\hline 2 & 16.67 \\
\hline 3 & 20.62 \\
\hline 4 & 23.05 \\
\hline 5 & 24.58 \\
\hline 6 & 25.13 \\
\hline 7 & 29.4 \\
\hline 8 & 30.1 \\
\hline
\end{tabular}

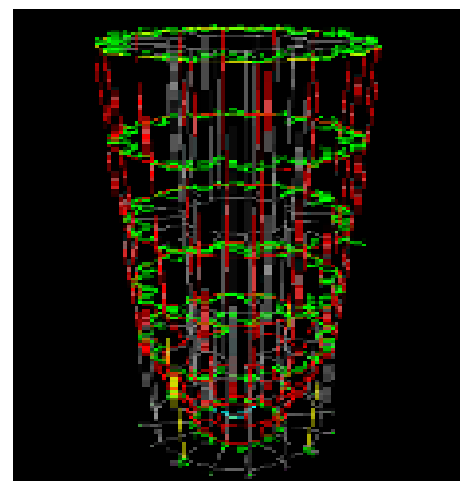

Fig : $13 \mathrm{D}$ view of RC silos with load assignment

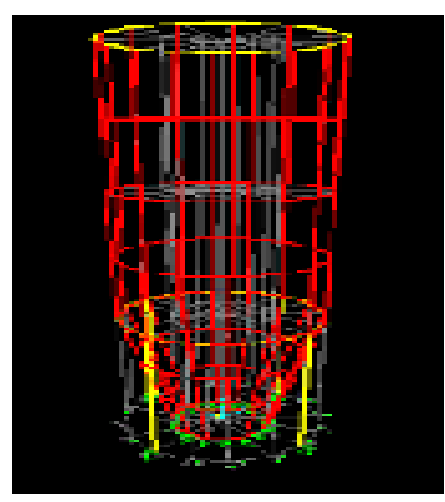

Fig : 2 3D View of Grid Line

\section{RESULTS AND DISCUSSION}

\section{A. Results and Discussion}

After applying loads on every layer then carrying out the analysis of the circular silo model, the results are obtained from SAP2000 and are as shown in Figure (3.0), Table (5). The hoop tension was also calculated manually using equation the manual calculation results are shown in Table (4.2).

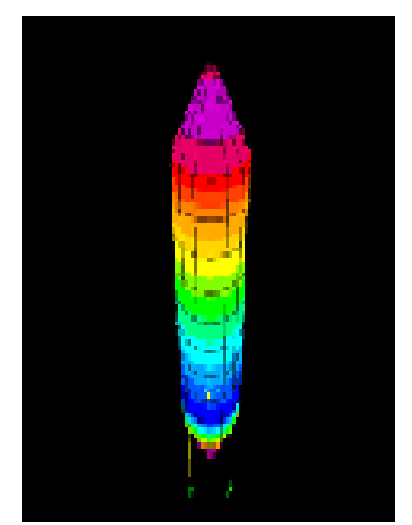

Fig:3 Diagram of tension on circular silo

Table (5): SAP hoop tension of circular silo

\begin{tabular}{|c|c|}
\hline \multirow{2}{*}{ Height(m) } & Hoop tension \\
\cline { 2 - 2 } & Sap 2000(N) \\
\hline 1 & 9950 \\
\hline 2 & 19599 \\
\hline 3 & 27326 \\
\hline 4 & 33719 \\
\hline 5 & 39120 \\
\hline 6 & 43445 \\
\hline
\end{tabular}


International Journal of Engineering Applied Sciences and Technology, 2020

Vol. 5, Issue 2, ISSN No. 2455-2143, Pages 328-332

Published Online June 2020 in IJEAST (http://www.ijeast.com)

\begin{tabular}{|l|l|}
\hline 7 & 48346 \\
\hline 8 & 51297 \\
\hline
\end{tabular}
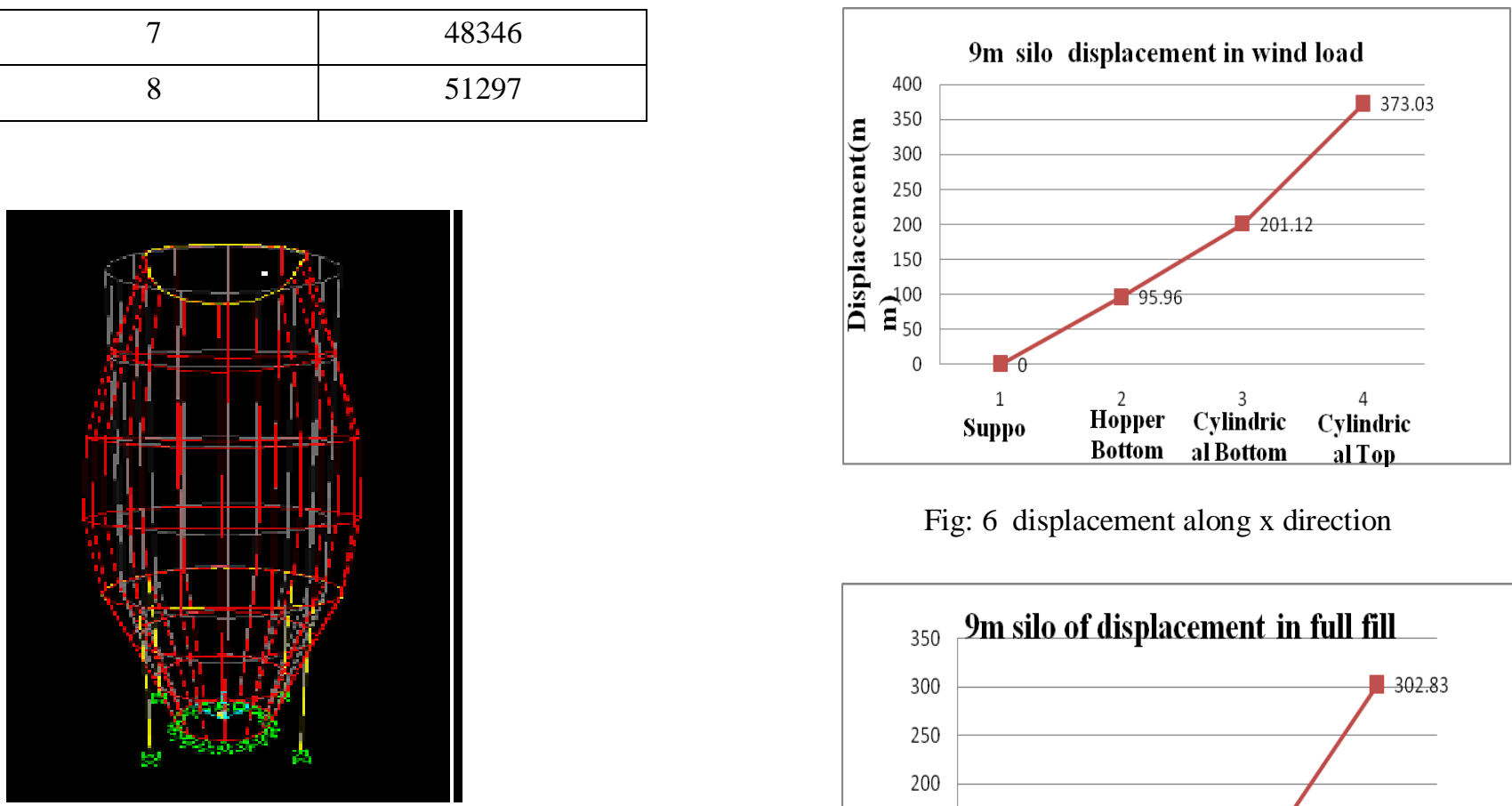

Fig: 6 displacement along $\mathrm{x}$ direction

Fig:4 mode shape $\mathrm{T}=0.00276$

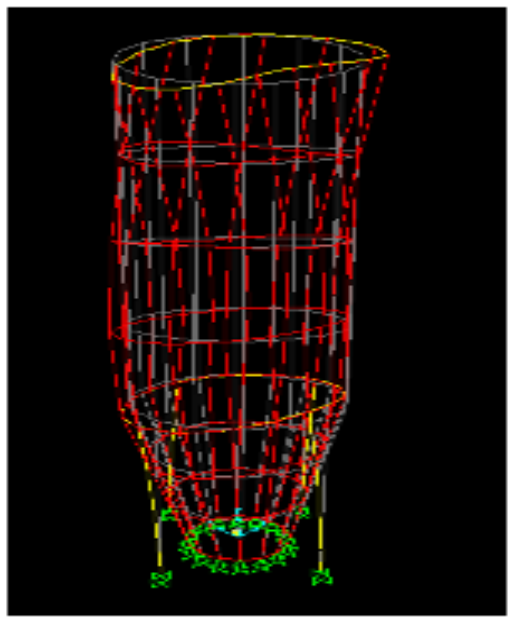

Fig: 5 mode shape $\mathrm{T}=0.00280$

Displacement graphs

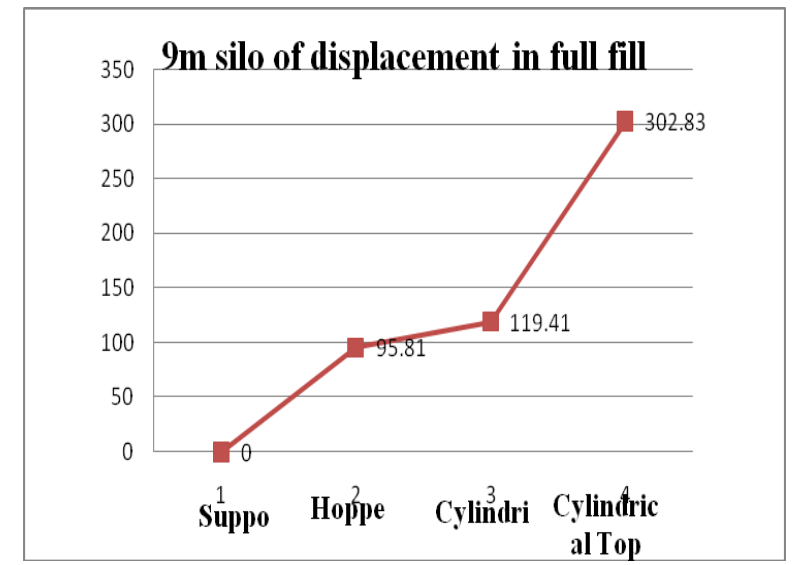

Fig:7 displacement along X Direction

\section{CONCLUSION}

1 The horizontal deflection is more in empty weight reinforced silo structure compare to full fill reinforced silo structure.

2 The hoop tension development in silo structure is less compare to manual calculation.

3 Manually digit error can increases. But by using software we can minimize these errors.

4 Manual analysis consume more time. by using software's we make the work fast.

\section{REFERENCES}

[1] Varun. G, Kavan M.R (2017) "Study Behavior of R C Silo For Lateral Loads Using Sap" Journal of Structural Engineering, Vol.5, No. 9, September 2017 @ (IJRASET)

[2] Harshavardan G. Patil, P .S. Patil (2019) Analysis of Steel Silos Subjected To Wind Load With Various Slenderness Ratios" journal of structural engineering, vol.6, no. 3, march 2019 @ (IRJET)

[3] Arun L, Mamatha K.K (2018) F E Analysis Of R C 
Circular Silo With Variation In Height And Hopper Angle With Constant Diameter Journal of Structural Engineering, Vol. 61, No.3, July 2018 @ (IJETT)

[4] Walid M.A. Khalifa , Khaled F. O.Ei- Kashef (2019) Evaluation of design of Rc silos subjected to thermal loads journal of structural engineering, vol.16, no. 3, February 2019(@ (JMCE)

[5] Halil sezen et al. (2019) cause of damage and failure in silo structures journal of structural engineering, ASCE

[6]Stefan Holler And Konstantin Meskouris (2006 )Granular Material Silos Under Dynamic Excitation : Numerical Simulation And Experimental Validation Journal of Structural Engineering,vol.132,no.10, October 2006@ ASCE

[7] Hamdy H.A. And Abdel -Rahim (2014) Response The Cylindrical Elevated Wheat storage Silos To Seismic Loading Journal of Structural Engineering, Vol.04, No.6, January 2014@ IOSRJEN

[8] James G.A. Croll(2006) Design Analysis For Buckling of Tanks And Silos Journal of Structural Engineering,vol.132,no.1, January 2006@ ASCE

[9] D .Briassoulis And D.A. Pecknlod (1986) Anchorage Requirement For Wind Loaded Empty Silos Journal Of Structural Engineering, Vol.112, No.2,february 1986@asce

[10] 'Advanced reinforced concrete design'-N Krishna Raju

[11] Standard codes IS 456-2000,IS 1893-2002,IS 4995,IS 875 part 3 